\title{
Effects of repeated gram-positive and gram-negative clinical mastitis episodes on milk yield loss in Holstein dairy cows
}

\author{
Y. H. Schukken, ${ }^{* 1}$ J. Hertl,† D. Bar,† G. J. Bennett, ${ }^{*}$ R. N. González, ${ }^{*}$ B. J. Rauch, ${ }^{*}$ C. Santisteban, ${ }^{*}$ \\ H. F. Schulte, ${ }^{*}$ L. Tauer,‡ F. L. Welcome, ${ }^{*}$ and Y. T. Gröhn† \\ ${ }^{*}$ Quality Milk Production Services, \\ †Section of Epidemiology, Department of Population Medicine and Diagnostic Sciences, College of Veterinary Medicine, and \\ ‡Department of Applied Economics and Management, College of Agriculture and Life Sciences, Cornell University, Ithaca, NY 14853
}

\begin{abstract}
The objective of this study was to estimate the effects of recurrent episodes of gram-positive and gramnegative cases of clinical mastitis (CM) on milk production in Holstein dairy cows. We were interested in the severity of repeated cases in general, but also in the severity of the host response as judged by milk production loss when a previous case was caused by a similar or different microorganism. The results were based on data from 7,721 primiparous lactations and 13,566 multiparous lactations in 7 large dairy herds in New York State. The distribution of organisms in the CM cases showed $28.5 \%$ gram-positive cases, $31.8 \%$ gram-negative cases, $15.0 \%$ others, and $24.8 \%$ with no organism identified. Mixed models, with a random herd effect and an autoregressive covariance structure to account for repeated measurements, were used to quantify the effect of repeated CM and several other control variables (parity, week of lactation, other diseases) on milk yield. Our data indicated that repeated CM cases showed a very similar milk loss compared with the first case. No reduction of severity was present with increasing count of the CM case. Gram-negative cases had more severe milk loss compared with gram-positive and other cases irrespective of the count of the case in lactation. Milk loss in multipara (primipara) due to gram-negative CM was approximately $304 \mathrm{~kg}(228 \mathrm{~kg}$ ) in the $50 \mathrm{~d}$ following $\mathrm{CM}$. This loss was approximately $128 \mathrm{~kg}(133 \mathrm{~kg})$ for gram-positive cases and $92 \mathrm{~kg}(112$ $\mathrm{kg}$ ) for other cases. The severity of a second case of gram-negative CM was not reduced by previous cases of gram-negative CM in multipara and only slightly less severe in a similar scenario in primipara cows. Similarly, a previous gram-positive case did not reduce severity of a second or third gram-positive case. Hence, our data do not support that immunological memory of
\end{abstract}

Received July 16, 2008

Accepted February 11, 2009.

${ }^{1}$ Corresponding author: yhs2@cornell.edu previous exposure to an organism in the same generic class provides protection for a next case of $\mathrm{CM}$ with an organism in the same class.

Key words: recurrent clinical mastitis, gram-positive, gram-negative, milk yield

\section{INTRODUCTION}

Clinical mastitis (CM) is an important disease of dairy cattle. It is associated with discomfort and loss of welfare of the cow. For the dairy producer it means an increase in labor and cow care efforts and a loss of saleable milk (Seegers et al., 2003). For this reason, a large amount of effort and resources is spent on preventative programs. Despite these preventative efforts, CM remains an important issue on virtually every dairy farm.

When a cow is diagnosed with CM, it is helpful to the dairy farmer to know what type of $\mathrm{CM}$ agent is causing the disease. The bacterial species causing the inflammation is partly responsible for the inflammatory response and clinical severity of a mastitis case (Bannerman, 2008). The species often determine the severity of the immune response of the cow and are often related to the amount of milk loss and severity of more systemic effects (Gröhn et al., 2004). It is therefore seen as important to determine, whenever feasible, the etiologic agent responsible. Treatment protocols are often specifically based on the knowledge of whether a clinical case is caused by a gram-negative or a gram-positive bacterial organism. The determination of gram-positive versus gram-negative may be based on simplified on-farm culture systems (Silva et al., 2005) or on data from commercial diagnostic laboratories. The outcome of these bacteriological cultures will assist the farmer in choosing the most appropriate treatment for a case (Erskine et al., 2003). Obviously, the degree of milk loss at both the cow and farm level plays a role in the farmer's effort to maximize profitability of the dairy. We previously showed that the first occurrences of gram-positive and gram-negative infections resulting in clinical cases are associated with a greater loss shown 
for gram-negative infections (Gröhn et al., 2004). Similarly, a difference was shown between these 2 groups of organisms for herd survival, where culling rates for gram-negative mastitis were very high in late lactation (Gröhn et al., 2005). These previous studies were based on analysis of the first case of CM in lactation. Cows often suffer multiple cases of CM in the same lactation (Houben et al., 1993; Zadoks et al., 2001), and these subsequent cases may show different clinical symptoms compared with the first case. It is important for the decision making of the dairy farmer to have a quantitative concept of the severity of repeated cases of mastitis. When subsequent cases turn out to be of decreasing clinical importance, then decision making should be particularly focused on first cases. On the other hand, when repeat cases show similar or increased severity compared with the first case, then these repeated cases may actually form the basis of many treatment and culling decisions in the dairy. Relatively little is known about the impact of repeated clinical cases on milk loss in dairy cows. Because long-term studies of cows, often over multiple lactations, are needed to obtain this information, most mastitis impact studies are limited to only one case of CM per lactation (for example, Bartlett et al., 1991).

When the second case of CM in the same lactation is caused by a different organism, it is unlikely that the cow has an immunological memory as a result of the first clinical case, particularly if the organisms are as different as gram-positive versus gram-negative. On the other hand, repeated cases of CM with the same organism or organisms in the same gram-classification (positive vs. negative) may result in relatively reduced severity, because the adaptive immune response may improve the cow's ability to mount an effective response to a second or third case (Burton and Erskine, 2003). Essentially, the concept of vaccination for intramammary infections and mastitis is based on this principle (Wilson and González, 2003). Several studies have shown that vaccination with a gram-negative coreantigen, which is present in all gram-negative organisms, results in reduced severity of clinical cases due to gram-negative mastitis (Wilson et al., 2007). It may be hypothesized that an actual case of gram-negative mastitis would serve as the ultimate vaccination and reduce severity of a next case of gram-negative mastitis in the same lactation. For gram-positive cases of mastitis, a protective effect of the first case on the severity of the second case is not as likely. Several vaccination attempts against gram-positive mastitis causing organisms (mostly Staphylococcus aureus and Streptococcus uberis) have shown limited or no efficacy (Yancey, 1999). The use of field data on repeated cases of grampositive mastitis might provide an indication whether a history of exposure to gram-positive organisms has the potential of reducing clinical severity of the next case of clinical mastitis with a gram-positive organism.

To be able to distinguish pathogen-specific clinical responses of repeated clinical cases, detailed long-term longitudinal studies are needed. Such studies where bacterial culture is combined with milk production data and herd survival have been scarce. Hence, relatively little quantitative information is available on differential losses of repeated cases as a function of the bacterial cause in the first versus the subsequent clinical cases.

The objective of this study was to estimate the effects of recurrent episodes of gram-positive and gram-negative cases of CM on milk production in Holstein dairy cows. We were interested in the severity of repeated cases in general, but also in the severity of the host response as judged by milk production loss when a previous case was caused by a similar or different microorganism.

\section{MATERIALS AND METHODS}

\section{Herd Descriptions}

The data came from 7 farms in New York State (1 in western New York, 2 in northern New York, and 4 in central New York). Cows were followed for 28 mo (4 farms), 34 mo (2 farms), or 46 mo (1 farm), across multiple lactations. Averaging over all farms, the rolling herd average was $11,320 \mathrm{~kg} / \mathrm{cow}$ per year on a $305-\mathrm{d}$ basis (range 10,710 to $11,560 \mathrm{~kg}$ ). Monthly mean SCC was approximately 225,000 cells/mL (monthly range from 181,000 to 355,000 ). Cows were housed in free stalls in covered barns and managed in groups or pens classified by lactation, production, and reproductive status. All cows were fed a balanced TMR and were milked 3 times daily. On each farm, milking units had milk meters that recorded milk production and milk conductivity. Farm personnel used DairyComp305 herd management software (Valley Agricultural Software, Tulare, CA) to record lactation, reproductive, and medical data for each cow. Data were available on parity, diseases, milk yield, drying-off, calving, and herd exit.

\section{Case Definition}

All lactating cows in the 7 herds were eligible for inclusion in the study. Milkers identified most CM cases (warm, swollen udder or changes in milk consistency). On 2 of the farms, some of the clinical cases were identified as cows whose milk electrical conductivity increased and milk production decreased. Cows with these characteristics were flagged and further examined for the presence of clinical signs of mastitis. Because the diagnostic criteria for each case were not recorded, 
Table 1. Classification of pathogens causing clinical mastitis (CM) in 7 New York State dairy herds

\begin{tabular}{lr}
\hline Pathogen & $\mathrm{n}^{1}$ \\
\hline Gram-positive & \\
Streptococcus spp. & 1,762 \\
Staphylococcus aureus & 432 \\
Staphylococcus spp. & 495 \\
Gram-negative & \\
Escherichia coli & 1,953 \\
Klebsiella spp. & 871 \\
Citrobacter & 102 \\
Enterobacter & 72 \\
Other & 224 \\
Arcanobacterium pyogenes & 53 \\
Mycoplasma & 43 \\
Corynebacterium bovis & 6 \\
Pseudomonas & 183 \\
Yeast & 907 \\
Others & 187 \\
Contamination & 477 \\
Unknown & 1,673 \\
No growth & \\
\hline
\end{tabular}

${ }^{1}$ Total number of $\mathrm{CM}$ cases (comprising first, second, and third occurrences) in which the pathogen was identified. A cow may have a mixture of organisms in any one episode.

it was not possible to evaluate the effect of diagnostic strategy on clinical severity. Sick cows were treated according to well-defined protocols that were similar (but not identical) in all 7 farms throughout the study. Farm personnel collected a single milk sample for microbiological culture from quarters with signs of CM. Samples were cultured by the Quality Milk Production Services laboratories (Ithaca, NY). The bacteriological culture procedures are described in detail in Gröhn et al. (2004). Results of the bacteriological culture were returned to the dairy producer, often within $24 \mathrm{~h}$, and used for selection of therapy. Therapy data were not consistently recorded on all farms and therefore not utilized in this analysis.

Table 1 shows how the CM pathogens collected in this study were classified. Classification was based on Gram staining. Our rationale for this classification was that gram-positive and gram-negative cases of $\mathrm{CM}$ often have different treatment and management protocols (Erskine et al., 2003). Generally, it is not recommended that gram-negative infections receive intramammary antimicrobial treatment (Yazdankhah et al., 2001; Erskine et al., 2003), whereas it is recommended that gram-positive infections are treated with intramammary antimicrobials. Similarly, negative culture results and other organisms were combined into an "other" category because most of these cases would not be treated with antimicrobials.

Some cows had 2 clinical episodes in the same quarter within a few days of each other. If the second episode occurred $\leq 5 \mathrm{~d}$ later with the same or a different patho- gen isolated, or occurred $\leq 14$ d later with the same pathogen isolated in both episodes, it was considered the same case of CM. Any episode occurring $>14 \mathrm{~d}$ after the previous episode, regardless of the pathogen isolated, was considered a new CM case (Barkema et al., 1998).

We fitted regression models on 4 reduced data sets for primipara and multipara separately. All these data sets included cows with no cases of CM to estimate production in healthy herdmates. In addition to these CMfree cows, the first data set contained cows whose first 2 cases were both gram-negative. The second data set also contained cows with the sequence of gram-negative $\mathrm{CM}$ and then gram-positive CM. The third data set also contained cows with a sequence of gram-positive, gram-positive CM. The fourth data set also contained cows that first had a case of gram-positive CM and then a case of gram-negative CM. In these analyses, the emphasis was on identifying the effect of the specific mastitis history on the severity of the second case of CM.

\section{Other Diseases}

Although gram-positive, gram-negative, and other $\mathrm{CM}$ cases were our main interest, we included 6 other diseases (milk fever, retained placenta, metritis, ketosis, displaced abomasum, and pneumonia) as potential confounders in the models. These are common clinical conditions in dairy cows, and may be associated with both mastitis and milk yield. We previously provided the definitions that were used for these 6 diseases (Bar et al., 2007). Written disease definitions were given to the participating dairy producers and veterinarians to ensure that disease definition and diagnostic criteria were consistent across herds.

\section{Statistical Methods}

We used PROC MIXED (SAS Institute, 2006) with a first-order autoregressive correlation structure among the repeated measurements of milk yield within an individual cow. Herd was modeled as a random effect, because our interest lay not in individual farms, but rather in farms in general with their characteristics (e.g., large and high producing, and with a low incidence of contagious mastitis). All other covariates [week-in-milk (WIM), calving season, CM types/cases, sequence of CM case occurrence, and other diseases] were modeled as fixed effects (Wilson et al., 2004). The first 3 CM episodes in a lactation were included in our analyses. Too few cows had 4 or more episodes to obtain valid estimates for the fourth and higher cases but the first 3 $\mathrm{CM}$ cases of these cows were included in the analyses. 
Table 2. Covariate coding scheme used in the statistical analysis of this study for 4 example cows ${ }^{1,2}$

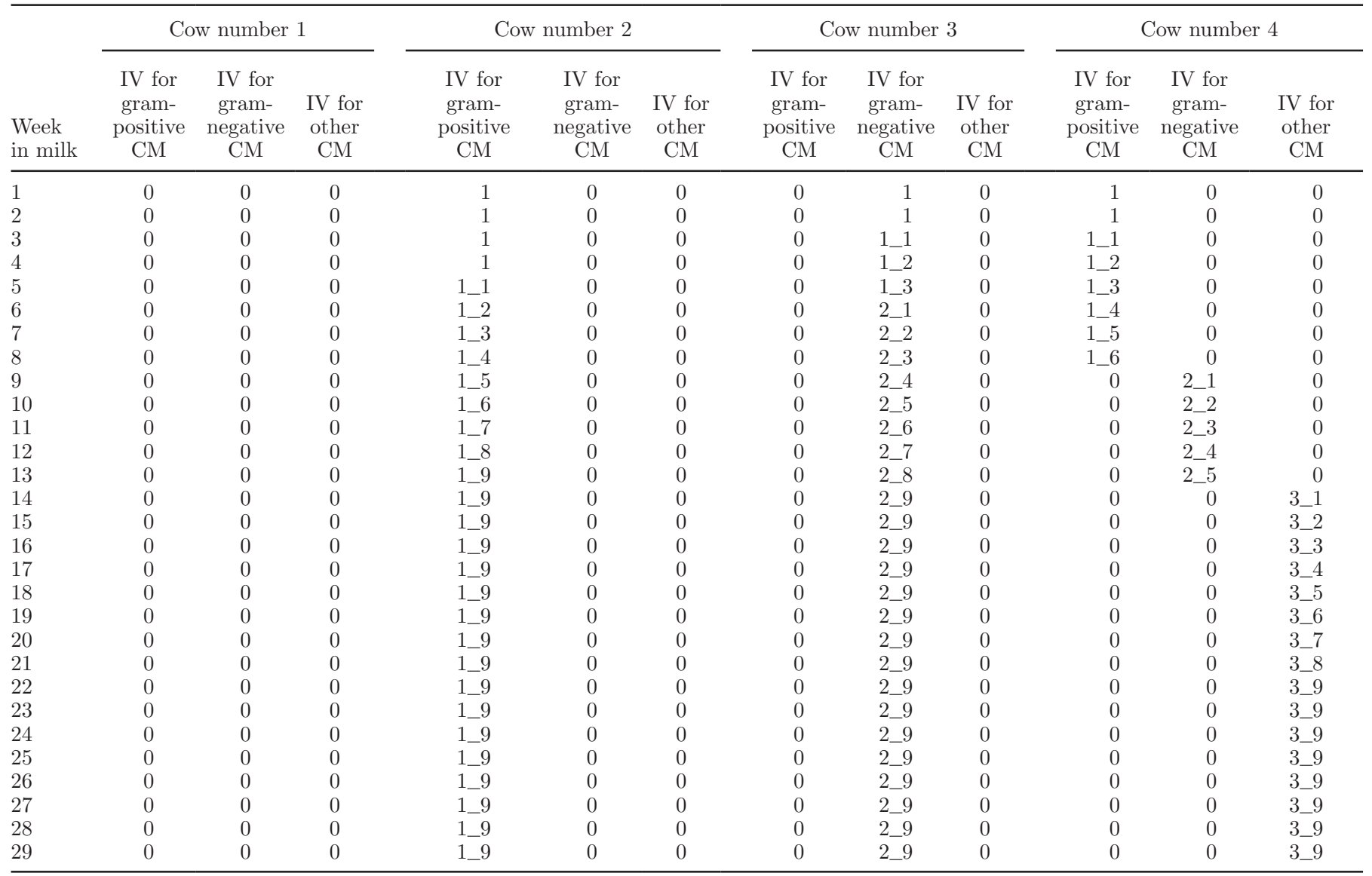

${ }^{1}$ The first cow did not have clinical mastitis $(\mathrm{CM})$; the second cow had 1 case of (gram-positive) CM occurring in wk 5 of lactation; the third cow had 2 cases of CM (both gram-negative), occurring in wk 3 and 6 of lactation; the fourth cow had 3 cases of CM (gram-positive, gram-negative, other), occurring in wk 3,9 , and 14 of lactation.

${ }^{2}$ The index variables (IV) indicate when milk weights were measured in relation to a specific type of CM occurrence: $0=$ free of that type of $\mathrm{CM}$; 1 = before first CM; 1_1 = week of first CM occurrence; $1 \_2=$ second week after first CM occurrence; $1 \_3=$ third week after first CM occurrence; $1 \_4=$ fourth week after first CM occurrence; $1 \_5=$ fifth week after first CM occurrence; $1 \_6=$ sixth week after first CM occurrence; $1 \_7$ $=$ seventh week after first $\mathrm{CM}$ occurrence; $1 \_8=$ eighth week after first CM occurrence; $1 \_9=$ nine or more weeks after first CM occurrence; $2 \_1$ = week of second CM occurrence; $2 \_2=$ second week after second CM occurrence . . 2_ $8=$ eighth week after second CM occurrence; $2 \_9$ $=$ nine or more weeks after second CM occurrence; $3 \_1=$ week of third CM occurrence; $3 \_2=$ second week after third CM occurrence ... 3_8 $=$ eighth week after third CM occurrence; $3 \_9=$ nine or more weeks after third CM occurrence.

For each episode, we identified whether this was 1 of 3 different types of CM: gram-positive, gram-negative, and "other" CM. Mixed infections were noted and categorized in the "other" category. The following linear mixed model was used:

$$
\begin{aligned}
\mathrm{Y}_{\mathrm{ijklm}}= & \text { Parity }_{\mathrm{i}}+\mathrm{WIM}_{\mathrm{j}}+\text { Other diseases }_{\mathrm{k}}+\mathrm{CM} \\
& + \text { Calving Season }_{\mathrm{l}}+\operatorname{Herd}_{\mathrm{m}}+e
\end{aligned}
$$

where $\mathrm{Y}_{\mathrm{ijklm}}$ is daily milk production $(\mathrm{kg} / \mathrm{d})$; Parity is used in the multipara model and contains 6 index variables for parity $\mathrm{i}=2,3,4,5,6$ and $\geq 7 ; \mathrm{WIM}_{\mathrm{j}}$ represents week in milk and contains 50 index variables for week $\mathrm{j}=1$ to 50 ; Other diseases $\mathrm{k}_{\mathrm{k}}$ was introduced above and contained 6 index variables; $\mathrm{CM}$ represents clinical mastitis with a coding that is presented in Table 2 . Table 2 illustrates the covariate coding scheme used in the current study for 4 example cows, 1 without CM, and the rest with either 1,2 , or $3 \mathrm{CM}$ cases. Calving season $_{1}$ contains 4 index variables for the 4 seasons; Herd $_{\mathrm{m}}$ is a random herd effect; and $e$ is a complex error term containing an autoregressive term and a random residual.

The outcome variable, Y, was measured in kilograms per day, and was a daily average of milk yield in a particular week. It was calculated by adding milk weights of the 3 daily milkings; then, within each WIM of lactation, 7 daily values were added and divided by 7 , resulting in mean daily milk yield in a particular 
Table 3. Distribution of pathogen sequences for the first 3 clinical mastitis (CM) cases in the lactations on 7 New York State dairy farms, by parity group

\begin{tabular}{|c|c|c|}
\hline Sequence of cases & $\begin{array}{c}\text { Parity } 1 \\
\text { (no. of lactations) }\end{array}$ & $\begin{array}{c}\text { Parity } 2+ \\
\text { (no. of lactations) }\end{array}$ \\
\hline No CM & 6,288 & 8,927 \\
\hline \multicolumn{3}{|l|}{1 case only } \\
\hline Gram-positive $^{1}$ & 337 & 722 \\
\hline Gram-negative $^{2}$ & 304 & 983 \\
\hline Other $^{3}$ - & 437 & 1,117 \\
\hline \multicolumn{3}{|l|}{2 cases only } \\
\hline Gram-positive, gram-positive & 26 & 117 \\
\hline Gram-positive, gram-negative & 19 & 65 \\
\hline Gram-negative, gram-positive & 12 & 68 \\
\hline Gram-negative, gram-negative & 34 & 158 \\
\hline Remaining options ${ }^{4}$ & 158 & 699 \\
\hline \multicolumn{3}{|l|}{3 cases } \\
\hline Gram-positive, gram-positive, gram-positive & 10 & 49 \\
\hline Gram-positive, gram-positive, gram-negative & 4 & 24 \\
\hline Gram-positive, gram-negative, gram-positive & 0 & 18 \\
\hline Gram-positive, gram-negative, gram-negative & 6 & 27 \\
\hline Gram-negative, gram-positive, gram-positive & 0 & 28 \\
\hline Gram-negative, gram-positive, gram-negative & 1 & 25 \\
\hline Gram-negative, gram-negative, gram-positive & 1 & 17 \\
\hline Gram-negative, gram-negative, gram-negative & 7 & 71 \\
\hline Remaining options $^{4}$ & 122 & 826 \\
\hline
\end{tabular}

${ }^{1}$ Such a case had a culture result that included a gram-positive organism. The culture may also have included a gram-negative or "other" organism; this also applies to sequences of 2 and 3 cases.

${ }^{2}$ Such a case had a culture result that included a gram-negative organism. The culture may also have included a gram-positive or "other" organism; this also applies to sequences of 2 and 3 cases.

${ }^{3}$ Such a case had a culture result that included an "other" organism. The culture may also have included a gram-positive or gram-negative organism; this also applies to sequences of 2 and 3 cases.

${ }^{4}$ Combinations that include "other" pathogens.

week of lactation (Bar et al., 2007). When missing data were encountered, the remaining days in the week were added and divided by the number of days for which data were not missing. Cows with CM were milked in the parlor as long as they were ambulatory, and milk production data were recorded on these animals and included in our analyses. Mixed models for the effects of type-specific (gram-positive, gram-negative, and other) recurrent $\mathrm{CM}$ cases were developed from work done previously by our group on the effects of recurrent cases of generic CM on milk yield (Bar et al., 2007). Primipara and multipara were modeled separately because their lactation curves have distinctly different shapes (Vasconcelos et al., 2004). Total milk loss due to a case of clinical mastitis was calculated by multiplying the daily loss in each week by 7 and then adding all estimated weekly losses for the duration of the presence of significant milk losses after the occurrence of the clinical case. These total losses were expressed as percentages of expected yield by calculating the expected yield for the same period base on healthy herd mates and corrected for the premastitis higher milk yield in CM cows. Because this was an observational study in commercial herds, cows were culled using the current culling strategies on the dairies. This may have affected the number of cows with repeated cases as these often are preferentially culled.

\section{RESULTS}

\section{Descriptive Findings}

The results were based on data from 7,721 primiparous lactations and 13,566 multiparous lactations in 7 herds. The distribution of organisms in the CM cases is shown in Table 1. The data resulted in an overall distribution of $28.5 \%$ gram-positive cases, $31.8 \%$ gramnegative cases, $15.0 \%$ others, and $24.8 \%$ with no organisms identified. Escherichia coli and Streptococcus spp. were most frequently isolated. The distribution of sequences of the first $3 \mathrm{CM}$ cases by type of $\mathrm{CM}$ (gram-positive, gram-negative, other) in a lactation in the study is shown in Table 3, for both primipara and multipara.

Clinical mastitis was more prevalent in multipara than in primipara, both overall and by type (grampositive, gram-negative, other). Thirty-two percent of multipara had at least one case of CM, whereas only $17 \%$ of primipara had at least one case of CM. Twelve percent and $5 \%$ of multipara had a second and third case of CM, respectively; the corresponding incidences 
in primipara were 4 and 1\%. Cases were evenly divided among types of CM, regardless of case number (first, second, third); that is, approximately one-third each were due to gram-positive, gram-negative, and other $\mathrm{CM}$, in both primipara and multipara. Clinical mastitis cases occurred earlier in lactation in multipara than in primipara. The incidence of an initial case of gramnegative $\mathrm{CM}$ was $5.0 \%$ for primiparous and $11 \%$ for multiparous cows. Of those, $12.6 \%$ (primiparous) and $19.4 \%$ (multiparous) had a second case of gram-negative CM. The incidence of a first case of gram-positive CM was $4.7 \%$ in primipara and $8.3 \%$ in multipara, and among animals with a previous case of gram-positive mastitis, the incidence of a second case of gram-positive CM was $11.0 \%$ in primipara and $20.3 \%$ in multipara. The mean (median) WIM for the first, second, and third cases in primipara were 19.9 (18), 28.1 (27.5), and 34.7 (35), respectively. The corresponding WIM in multipara were 17.1 (14), 24.1 (22), and 28.2 (27), respectively.

\section{Milk Losses Associated with Gram-Positive, Gram-Negative, and Other CM Episodes}

Milk loss estimates for the first 3 cases of $\mathrm{CM}$ varied with case number and type of CM in primipara and are presented in Table 4. In all analyses, the other diseases showed a significant negative effect on milk production as we have reported before (Gröhn et al., 2004; Bar et al., 2007); however, no interactions with $\mathrm{CM}$ variables were observed. Before the first case of CM occurred, all primiparous $\mathrm{CM}$ animals, regardless of which type of $\mathrm{CM}$ they went on to contract, produced more $(P$ $<0.006)$ milk than their non-CM herdmates. Among first and second cases, gram-negative infections caused greater milk loss than did gram-positive or "other" clinical cases. For gram-positive CM cases, milk loss increased with increasing count of CM cases. The highest milk loss in the first week after mastitis was $2.0 \mathrm{~kg} / \mathrm{d}$ for the first case and 3.1 and $6.5 \mathrm{~kg} / \mathrm{d}$ for the second and third cases, respectively. In the gram-negative CM cases, very little difference in milk loss was seen between the counts of the CM case. Other CM cases had a relatively limited milk loss for the first and second cases, but a loss very similar to the gram-negative cases for the third case in the same cow in the same lactation. The data in Tables 4 and 5 do not differentiate between any order of cases in lactation, so a third case of gramnegative mastitis could be preceded by gram-positive, gram-negative, or "other" case.

As with primipara, multiparous cows with $\mathrm{CM}$ had greater $(P<0.0004)$ milk yield before onset of $\mathrm{CM}$ than did their non-CM herdmates, regardless of $\mathrm{CM}$ type (Table 5). Gram-negative CM cases were associ- ated with greater milk loss than were gram-positive or other cases, regardless of the case number. Milk losses associated with "other" infections were relatively small in all 3 cases. In gram-positive CM cases there was not much evidence for decreasing severity (lower milk loss) with increasing case number; the highest losses were in the third case in lactation, followed by the first and second cases. Gram-negative CM cases showed the highest loss in the first case, followed by the second and third case. The differences between the first, second, and third cases were small (approximately $0.5 \mathrm{~kg} / \mathrm{d}$ reduced loss with increasing case number).

Milk loss in multipara (primipara) due to gramnegative CM was approximately $304 \mathrm{~kg}(228 \mathrm{~kg})$ in the $50 \mathrm{~d}$ following CM. This loss was approximately $128 \mathrm{~kg}$ (133 kg) for gram-positive cases and $92 \mathrm{~kg}(112 \mathrm{~kg})$ for other cases (Tables 4 and 5). Milk production loss as a percentage of milk production expectation at the time of occurrence of the clinical case remained constant or slightly increased with increasing case number. Estimated loss of milk for multipara was 128, 93, and 193 $\mathrm{kg}$ for the first, second, and third cases of gram-positive $\mathrm{CM}$, respectively, and 304, 276, and $295 \mathrm{~kg}$ for the first, second, and third cases of gram-negative mastitis, respectively (Table 5). As a percentage of estimated milk production during the 7 wk after the case of CM, it was $5.6,4.5$, and $9.8 \%$ for the first 3 gram-positive cases and $12.6,12.0$, and $13.7 \%$ for the first 3 gram-negative cases, respectively (Table 5). For "other" cases the milk loss and percentage milk loss were, for multipara, in the first 3 cases respectively $92.4(3.8 \%), 126.7(5.2 \%)$, and $73.5 \mathrm{~kg}(3.0 \%)$.

In analyzing the separate data sets with only cows with 2 cases of known gram-positive or gram-negative mastitis and all control cows, we attempted to identify possible protective effects of a previous case of CM with an organism of the same Gram-stain classification. In primipara, when the second CM case was gram-negative, its impact varied slightly depending on whether the first case was gram-positive or gram-negative (Table 6, Figure 1). When the first case was gram-positive, milk loss associated with a subsequent gram-negative case was greater 1 wk after diagnosis compared with the situation where the first case was gram-negative $(5.5 \mathrm{~kg} / \mathrm{d}$ lost for the gram-positive, gram-negative sequence compared with approximately $4.1 \mathrm{~kg} / \mathrm{d}$ lost for the gram-negative, gram-negative sequence). Similarly, a previous case of gram-negative mastitis appeared to reduce severity of milk loss at 3 to 4 wk after diagnosis $(4.4 \mathrm{~kg} / \mathrm{d}$ lost for the gram-positive, gram-negative sequence compared with approximately $3.3 \mathrm{~kg} / \mathrm{d}$ lost for the gram-negative, gram-negative sequence). In contrast, milk loss when the second CM case was gram-positive was higher in the week of CM diagnosis and 3 to 5 wk after diagnosis 
Table 4. Effect (kg/d of milk) estimates of mixed model of the first 3 occurrences of 3 types of clinical mastitis (CM; gram-positive, gram-negative, and other) on milk yield in 7,721 parity 1 cows on 7 New York State dairy farms

\begin{tabular}{|c|c|c|c|c|c|c|c|c|c|c|c|c|c|c|c|c|c|c|}
\hline \multirow[b]{3}{*}{ Time $^{1}$} & \multicolumn{6}{|c|}{ Gram-positive CM } & \multicolumn{6}{|c|}{ Gram-negative CM } & \multicolumn{6}{|c|}{ Other CM } \\
\hline & \multicolumn{2}{|c|}{ First CM } & \multicolumn{2}{|c|}{ Second CM } & \multicolumn{2}{|c|}{ Third CM } & \multicolumn{2}{|c|}{ First CM } & \multicolumn{2}{|c|}{ Second CM } & \multicolumn{2}{|c|}{ Third CM } & \multicolumn{2}{|c|}{ First CM } & \multicolumn{2}{|c|}{ Second CM } & \multicolumn{2}{|c|}{ Third CM } \\
\hline & $\mathrm{Est}^{2}$ & $95 \% \mathrm{CI}^{3}$ & Est & $95 \%$ CI & Est & $95 \% \mathrm{CI}$ & Est & $95 \%$ CI & Est & $95 \%$ CI & Est & $95 \% \mathrm{CI}$ & Est & $95 \%$ CI & Est & $95 \% \mathrm{CI}$ & Est & $95 \% \mathrm{CI}$ \\
\hline Before CM & 0.5 & $\begin{array}{l}0.2 \\
0.9\end{array}$ & - & - & - & - & 1.1 & $\begin{array}{l}0.7 \\
1.5\end{array}$ & - & - & - & - & 0.9 & $\begin{array}{l}0.5 \\
1.3\end{array}$ & - & - & - & - \\
\hline Same week & -2.6 & $\begin{array}{l}-3.0 \\
-2.1\end{array}$ & -3.1 & $\begin{array}{l}-4.0 \\
-2.3\end{array}$ & -3.1 & $\begin{array}{l}-5.0 \\
-1.3\end{array}$ & -4.6 & $\begin{array}{l}-5.1 \\
-4.1\end{array}$ & -4.6 & $\begin{array}{l}-5.4 \\
-3.8\end{array}$ & -5.6 & $\begin{array}{l}-7.1 \\
-4.1\end{array}$ & -2.5 & $\begin{array}{l}-2.9 \\
-2.0\end{array}$ & -2.2 & $\begin{array}{l}-2.9 \\
-1.6\end{array}$ & -3.5 & $\begin{array}{l}-4.8 \\
-2.2\end{array}$ \\
\hline$+1 \mathrm{wk}$ & -2.0 & $\begin{array}{l}-2.5 \\
-1.5\end{array}$ & -3.1 & $\begin{array}{l}-4.2 \\
-2.0\end{array}$ & -6.5 & $\begin{array}{l}-8.8 \\
-4.3\end{array}$ & -5.2 & $\begin{array}{l}-5.8 \\
-4.7\end{array}$ & -4.8 & $\begin{array}{l}-5.8 \\
-3.8\end{array}$ & -3.6 & $\begin{array}{l}-5.5 \\
-1.7\end{array}$ & -2.9 & $\begin{array}{l}-3.4 \\
-2.3\end{array}$ & -2.2 & $\begin{array}{l}-3.0 \\
-1.4\end{array}$ & -5.3 & $\begin{array}{l}-6.9 \\
-3.8\end{array}$ \\
\hline$+2 \mathrm{wk}$ & -1.5 & $\begin{array}{l}-2.0 \\
-0.9\end{array}$ & -2.6 & $\begin{array}{l}-3.8 \\
-1.4\end{array}$ & -6.0 & $\begin{array}{l}-8.7 \\
-3.4\end{array}$ & -3.8 & $\begin{array}{l}-4.4 \\
-3.2\end{array}$ & -4.8 & $\begin{array}{l}-6.0 \\
-3.6\end{array}$ & -3.8 & $\begin{array}{l}-5.9 \\
-1.8\end{array}$ & -1.8 & $\begin{array}{l}-2.4 \\
-1.2\end{array}$ & -1.9 & $\begin{array}{l}-2.8 \\
-1.1\end{array}$ & -5.2 & $\begin{array}{l}-6.9 \\
-3.5\end{array}$ \\
\hline$+3 \mathrm{wk}$ & -1.3 & $\begin{array}{l}-1.9 \\
-0.8\end{array}$ & -2.9 & $\begin{array}{l}-4.2 \\
-1.5\end{array}$ & -4.9 & $\begin{array}{l}-8.0 \\
-1.8\end{array}$ & -2.3 & $\begin{array}{l}-3.0 \\
-1.7\end{array}$ & -4.1 & $\begin{array}{l}-5.3 \\
-2.8\end{array}$ & -3.2 & $\begin{array}{l}-5.4 \\
-1.0\end{array}$ & -1.5 & $\begin{array}{l}-2.1 \\
-0.9\end{array}$ & -0.7 & $\begin{array}{r}-1.7 \\
0.3\end{array}$ & -4.5 & $\begin{array}{l}-6.3 \\
-2.7\end{array}$ \\
\hline$+4 \mathrm{wk}$ & -0.9 & $\begin{array}{l}-1.5 \\
-0.4\end{array}$ & -2.9 & $\begin{array}{l}-4.4 \\
-1.5\end{array}$ & -2.2 & $\begin{array}{c}-5.5 \\
1.1\end{array}$ & -1.9 & $\begin{array}{l}-2.5 \\
-1.3\end{array}$ & -3.5 & $\begin{array}{l}-4.8 \\
-2.3\end{array}$ & -4.1 & $\begin{array}{l}-6.4 \\
-1.9\end{array}$ & -1.3 & $\begin{array}{l}-1.9 \\
-0.7\end{array}$ & -0.5 & $\begin{array}{c}-1.6 \\
0.5\end{array}$ & -4.3 & $\begin{array}{l}-6.3 \\
-2.3\end{array}$ \\
\hline$+5 \mathrm{wk}$ & -0.9 & $\begin{array}{l}-1.5 \\
-0.3\end{array}$ & -3.2 & $\begin{array}{l}-4.7 \\
-1.6\end{array}$ & -0.9 & $\begin{array}{c}-4.1 \\
2.2\end{array}$ & -1.6 & $\begin{array}{l}-2.2 \\
-1.0\end{array}$ & -3.2 & $\begin{array}{l}-4.5 \\
-1.9\end{array}$ & -0.2 & $\begin{array}{c}-2.5 \\
2.1\end{array}$ & -1.1 & $\begin{array}{l}-1.7 \\
-0.4\end{array}$ & -0.1 & $\begin{array}{c}-1.2 \\
0.9\end{array}$ & -4.6 & $\begin{array}{l}-6.7 \\
-2.6\end{array}$ \\
\hline$+6 \mathrm{wk}$ & -0.8 & $\begin{array}{l}-1.3 \\
-0.2\end{array}$ & -3.6 & $\begin{array}{l}-5.2 \\
-2.1\end{array}$ & -0.2 & $\begin{array}{c}-3.5 \\
3.1\end{array}$ & -1.3 & $\begin{array}{l}-1.9 \\
-0.6\end{array}$ & -3.4 & $\begin{array}{l}-4.7 \\
-2.0\end{array}$ & -1.2 & $\begin{array}{c}-3.6, \\
1.2\end{array}$ & -1.0 & $\begin{array}{l}-1.6 \\
-0.4\end{array}$ & -0.8 & $\begin{array}{c}-1.9 \\
0.3\end{array}$ & -5.6 & $\begin{array}{l}-7.8 \\
-3.4\end{array}$ \\
\hline$+7 \mathrm{wk}$ & -0.7 & $\begin{array}{l}-1.3 \\
-0.2\end{array}$ & -1.6 & $\begin{array}{l}-3.1 \\
-0.1\end{array}$ & -0.6 & $\begin{array}{r}-3.7 \\
2.5\end{array}$ & -0.8 & $\begin{array}{l}-1.4 \\
-0.3\end{array}$ & -3.5 & $\begin{array}{l}-4.7 \\
-2.2\end{array}$ & -1.1 & $\begin{array}{c}-3.4 \\
1.2\end{array}$ & -0.4 & $\begin{array}{c}-1.0 \\
0.1\end{array}$ & -1.0 & $\begin{array}{c}-2.0 \\
0.1\end{array}$ & -4.4 & $\begin{array}{l}-6.5 \\
-2.3\end{array}$ \\
\hline $\begin{array}{l}+8 \text { wk } \\
\text { and after }\end{array}$ & -0.9 & $\begin{array}{l}-1.4 \\
-0.4\end{array}$ & -0.4 & $\begin{array}{c}-1.6 \\
0.8\end{array}$ & 0.7 & $\begin{array}{c}-1.8 \\
3.1\end{array}$ & -0.3 & $\begin{array}{c}-0.8 \\
0.2\end{array}$ & -2.7 & $\begin{array}{l}-3.7 \\
-1.7\end{array}$ & -2.2 & $\begin{array}{l}-4.3 \\
-0.2\end{array}$ & -0.5 & $\begin{array}{l}-1.0 \\
-0.1\end{array}$ & -1.8 & $\begin{array}{l}-2.7 \\
-0.9\end{array}$ & -3.6 & $\begin{array}{l}-5.2 \\
-1.9\end{array}$ \\
\hline $\begin{array}{l}{ }^{1} \text { Time of mi } \\
{ }^{2} \text { Est }=\text { estin } \\
{ }^{3} \mathrm{CI}=\text { confic }\end{array}$ & $\begin{array}{l}\text { meas } \\
\text { ate. } \\
\text { ence in }\end{array}$ & $\begin{array}{l}\text { urement } \\
\text { terval. }\end{array}$ & & to diseas & Irrenc & & & & & & & & & & & & & \\
\hline
\end{tabular}


Table 5. Effect $(\mathrm{kg} / \mathrm{d})$ estimates of mixed model of the first 3 occurrences of 3 types of clinical mastitis (CM; gram-positive, gram-negative, and other) on milk yield in 13,566 parity $2+$ cows on 7 New York State dairy farms

\begin{tabular}{|c|c|c|c|c|c|c|c|c|c|c|c|c|c|c|c|c|c|c|}
\hline \multirow[b]{3}{*}{ Time $^{1}$} & \multicolumn{6}{|c|}{ Gram-positive CM } & \multicolumn{6}{|c|}{ Gram-negative CM } & \multicolumn{6}{|c|}{ Other CM } \\
\hline & \multicolumn{2}{|c|}{ First CM } & \multicolumn{2}{|c|}{ Second CM } & \multicolumn{2}{|c|}{ Third CM } & \multicolumn{2}{|c|}{ First CM } & \multicolumn{2}{|c|}{ Second CM } & \multicolumn{2}{|c|}{ Third CM } & \multicolumn{2}{|c|}{ First CM } & \multicolumn{2}{|c|}{ Second CM } & \multicolumn{2}{|c|}{ Third CM } \\
\hline & Est $^{2}$ & $95 \% \mathrm{CI}^{3}$ & Est & $95 \% \mathrm{CI}$ & Est & $95 \%$ CI & Est & $95 \% \mathrm{CI}$ & Est & $95 \% \mathrm{CI}$ & Est & $95 \% \mathrm{CI}$ & Est & $95 \%$ CI & Est & $95 \% \mathrm{CI}$ & Est & $95 \% \mathrm{CI}$ \\
\hline Before CM & 0.6 & $\begin{array}{l}0.3 \\
0.9\end{array}$ & - & - & - & - & 2.4 & $\begin{array}{l}2.1 \\
2.7\end{array}$ & - & - & - & - & 0.6 & $\begin{array}{l}0.3 \\
0.9\end{array}$ & - & - & - & - \\
\hline Same week & -3.5 & $\begin{array}{l}-3.9 \\
-3.1\end{array}$ & -2.7 & $\begin{array}{l}-3.2 \\
-2.2\end{array}$ & -4.0 & $\begin{array}{l}-4.9 \\
-3.2\end{array}$ & -5.8 & $\begin{array}{l}-6.1 \\
-5.4\end{array}$ & -6.0 & $\begin{array}{l}-6.5 \\
-5.5\end{array}$ & -4.4 & $\begin{array}{l}-5.1 \\
-3.6\end{array}$ & -3.5 & $\begin{array}{l}-3.8 \\
-3.1\end{array}$ & -3.0 & $\begin{array}{l}-3.5 \\
-2.6\end{array}$ & -2.7 & $\begin{array}{l}-3.4 \\
-2.0\end{array}$ \\
\hline$+1 \mathrm{wk}$ & -3.3 & $\begin{array}{l}-3.7 \\
-2.8\end{array}$ & -2.4 & $\begin{array}{l}-3.1 \\
-1.8\end{array}$ & -4.7 & $\begin{array}{l}-5.8 \\
-3.6\end{array}$ & -8.3 & $\begin{array}{l}-8.6 \\
-7.9\end{array}$ & -6.5 & $\begin{array}{l}-7.1 \\
-5.9\end{array}$ & -5.1 & $\begin{array}{l}-6.1 \\
-4.1\end{array}$ & -2.3 & $\begin{array}{l}-2.7 \\
-1.9\end{array}$ & -3.1 & $\begin{array}{l}-3.6 \\
-2.5\end{array}$ & -2.5 & $\begin{array}{l}-3.4 \\
-1.7\end{array}$ \\
\hline$+2 \mathrm{wk}$ & -2.3 & $\begin{array}{l}-2.7 \\
-1.8\end{array}$ & -1.7 & $\begin{array}{l}-2.4 \\
-1.0\end{array}$ & -3.2 & $\begin{array}{l}-4.5 \\
-2.0\end{array}$ & -5.1 & $\begin{array}{l}-5.5 \\
-4.7\end{array}$ & -4.5 & $\begin{array}{l}-5.2 \\
-3.8\end{array}$ & -3.9 & $\begin{array}{l}-5.0 \\
-2.8\end{array}$ & -1.6 & $\begin{array}{l}-2.0 \\
-1.2\end{array}$ & -1.7 & $\begin{array}{l}-2.3 \\
-1.1\end{array}$ & -1.0 & $\begin{array}{l}-1.9 \\
-0.0\end{array}$ \\
\hline+3 wk & -1.8 & $\begin{array}{l}-2.2 \\
-1.3\end{array}$ & -1.3 & $\begin{array}{l}-2.1 \\
-0.5\end{array}$ & -3.6 & $\begin{array}{l}-4.9 \\
-2.2\end{array}$ & -3.2 & $\begin{array}{l}-3.7 \\
-2.8\end{array}$ & -2.8 & $\begin{array}{l}-3.6 \\
-2.1\end{array}$ & -3.5 & $\begin{array}{l}-4.7 \\
-2.2\end{array}$ & -1.1 & $\begin{array}{l}-1.5 \\
-0.6\end{array}$ & -1.2 & $\begin{array}{l}-1.9 \\
-0.5\end{array}$ & -0.6 & $\begin{array}{c}-1.6 \\
0.4\end{array}$ \\
\hline$+4 \mathrm{wk}$ & -1.3 & $\begin{array}{l}-1.9 \\
-0.8\end{array}$ & -1.1 & $\begin{array}{l}-2.0 \\
-0.3\end{array}$ & -2.8 & $\begin{array}{l}-4.3 \\
-1.4\end{array}$ & -2.3 & $\begin{array}{l}-2.7 \\
-1.8\end{array}$ & -1.5 & $\begin{array}{l}-2.3 \\
-0.7\end{array}$ & -2.9 & $\begin{array}{l}-4.2 \\
-1.7\end{array}$ & -0.5 & $\begin{array}{c}-0.9 \\
0.0\end{array}$ & -1.4 & $\begin{array}{l}-2.1 \\
-0.6\end{array}$ & 0.0 & $\begin{array}{c}-1.0 \\
1.1\end{array}$ \\
\hline$+5 \mathrm{wk}$ & -1.2 & $\begin{array}{l}-1.7 \\
-0.7\end{array}$ & -0.2 & $\begin{array}{c}-1.1 \\
0.7\end{array}$ & -3.2 & $\begin{array}{l}-4.6 \\
-1.7\end{array}$ & -1.3 & $\begin{array}{l}-1.8 \\
-0.9\end{array}$ & -0.7 & $\begin{array}{c}-1.6 \\
0.1\end{array}$ & -3.1 & $\begin{array}{l}-4.4 \\
-1.9\end{array}$ & -0.3 & $\begin{array}{c}-0.7 \\
0.2\end{array}$ & -1.8 & $\begin{array}{l}-2.6 \\
-1.1\end{array}$ & 0.2 & $\begin{array}{c}-0.9 \\
1.3\end{array}$ \\
\hline$+6 \mathrm{wk}$ & -0.7 & $\begin{array}{l}-1.2 \\
-0.2\end{array}$ & 0.3 & $\begin{array}{c}-0.6 \\
1.2\end{array}$ & -1.9 & $\begin{array}{l}-3.3 \\
-0.4\end{array}$ & -0.7 & $\begin{array}{l}-1.1 \\
-0.2\end{array}$ & -0.6 & $\begin{array}{c}-1.4, \\
0.3\end{array}$ & -2.4 & $\begin{array}{l}-3.6 \\
-1.1\end{array}$ & 0.3 & $\begin{array}{c}-0.2 \\
0.7\end{array}$ & -1.7 & $\begin{array}{l}-2.5 \\
-0.9\end{array}$ & 0.3 & $\begin{array}{c}-0.8 \\
1.4\end{array}$ \\
\hline$+7 \mathrm{wk}$ & -0.4 & $\begin{array}{c}-0.9 \\
0.1\end{array}$ & 0.1 & $\begin{array}{c}-0.8 \\
1.0\end{array}$ & -0.9 & $\begin{array}{r}-2.3 \\
0.4\end{array}$ & -0.2 & $\begin{array}{c}-0.6 \\
0.3\end{array}$ & 0.4 & $\begin{array}{c}-0.4 \\
1.2\end{array}$ & -1.6 & $\begin{array}{l}-2.8 \\
-0.5\end{array}$ & 0.7 & $\begin{array}{l}0.2 \\
1.1\end{array}$ & -1.2 & $\begin{array}{l}-2.0 \\
-0.5\end{array}$ & 0.9 & $\begin{array}{c}-0.2 \\
1.9\end{array}$ \\
\hline $\begin{array}{l}+8 \text { wk } \\
\text { and after }\end{array}$ & -0.2 & $\begin{array}{c}-0.6 \\
0.2\end{array}$ & 1.0 & $\begin{array}{l}0.2 \\
1.8\end{array}$ & -1.3 & $\begin{array}{l}-2.5 \\
-0.2\end{array}$ & 0.2 & $\begin{array}{c}-0.2 \\
0.5\end{array}$ & 0.8 & $\begin{array}{l}0.2 \\
1.5\end{array}$ & -1.4 & $\begin{array}{l}-2.4 \\
-0.4\end{array}$ & 0.7 & $\begin{array}{l}0.3 \\
1.1\end{array}$ & -1.2 & $\begin{array}{l}-1.8 \\
-0.5\end{array}$ & 0.9 & $\begin{array}{l}0.0 \\
1.8\end{array}$ \\
\hline
\end{tabular}

${ }^{1}$ Time of milk measurement in relation to disease occurrence.

${ }^{2}$ Est $=$ estimate.

${ }^{3} \mathrm{CI}=$ confidence interval. 
in cows with the gram-positive, gram-positive sequence (5.3 and $>4.5 \mathrm{~kg} / \mathrm{d}$, respectively) compared with the gram-negative, gram-positive sequence $(2.5$ and $<2.3$ $\mathrm{kg} / \mathrm{d}$, respectively; Table 6 , Figure 1).

For multipara, milk loss associated with a second gram-negative case was somewhat higher when the first case was gram-negative than if the first case was grampositive, in all of the first $6 \mathrm{wk}$ after diagnosis (Table 7, Figure 2). In the first week after diagnosis, a second gram-negative CM case was associated with a $7.9-\mathrm{kg}$ milk loss if the first case was also gram-negative, but only $5.6 \mathrm{~kg} / \mathrm{d}$ when the first case was gram-positive. Milk loss associated with a second gram-positive case tended to be higher when the first case was gramnegative compared with that in cows where the first case was gram-positive (Table 7).

Figure 1A shows lactation curves for 4 primipara, 1 free of $\mathrm{CM}$ and the others experiencing one case only of CM (gram-positive, gram-negative, or other) during lactation. It was assumed that CM occurred during the median week of occurrence for the first case of each type; that is, 18 WIM for gram-positive CM and gramnegative CM and 19 WIM for other CM. All of the mastitic animals produced more milk, before diagnosis, than did nonmastitic cows. Animals with a case of gram-negative CM experienced the greatest loss of milk around the time of diagnosis. The patterns of milk loss were similar for gram-positive and "other" CM animals, but slightly shifted in time.

Figure 1B shows lactation curves for primipara with no CM, and 4 sequences of 2 cases of CM (grampositive, gram-positive; gram-positive, gram-negative; gram-negative, gram-positive; and gram-negative, gramnegative). Clinical mastitis cases were assumed to occur during the median week of occurrence for each case/ type of CM; for example, for the gram-positive, grampositive sequence, the median weeks of occurrence were 18 and 28, respectively. Before CM diagnosis, mastitic animals yielded more milk than did non-CM ones. Milk loss patterns were similar among the CM animals until approximately $34 \mathrm{wk}$ in lactation. At this point, milk yield increased for animals whose second CM case was gram-positive, but continued decreasing for those whose second CM case was gram-negative. When comparing the estimated yields for animals with 2 consecutive gram-negative CM cases with the yields of animals with first a gram-positive and then a gram-negative case, it becomes evident that a preceding gram-negative CM case does not offer much protection against subsequent losses of a second gram-negative CM case. The same is true for the second gram-positive CM case where a previous gram-positive CM case had a slight negative effect on milk loss compared with that in animals with a sequence of a gram-negative and then gram-positive CM case.

Lactation curves for primiparous animals without $\mathrm{CM}$ and animals with selected sequences of 3 cases of $\mathrm{CM}$ during lactation are shown in Figure 1C. All cases of CM were assumed to occur during the median week of occurrence for each case/type; for example, for the gram-negative, gram-positive, gram-positive sequence, the median weeks of occurrence were 19, 28, and 38 . Mastitic primipara were higher yielders until the first case of CM. Until the third case of CM had occurred, the lactation curves had roughly the same shape. When the third case occurred, however, milk yield became rather erratic, depending on the sequence of types. When subsequent cases were gram-negative, milk yield was particularly adversely affected, regardless of whether the first case was gram-positive or gram-negative. The milk yield of all mastitic animals remained well below that of non-CM animals after the first case of CM was diagnosed and for the remainder of lactation.

Four lactation curves for multipara are displayed in Figure 2A, one for a non-CM cow, and the others for cows with a single case (gram-positive, gram-negative, or other) of $\mathrm{CM}$ in lactation. Clinical mastitis was assumed to occur during the median week of occurrence for each type. The CM cows, particularly the cow with gram-negative CM, had higher milk yield before diagnosis. However, a sharp drop in yield occurred at diagnosis. Milk yield recovered to some extent after several weeks, but remained below that of non-CM cows.

Multipara with 2 cases of CM (assumed to occur during the median week of occurrence for each case/ type) experienced sharp drops in milk yield at each case (Figure 2B). Gram-negative bacteria were responsible for larger milk losses associated with the first case, compared with losses from gram-positive cases. Similarly, milk loss was greater when the second case of CM was gram-negative than when it was gram-positive. As in the primipara, there was no evidence for a protective effect of a first gram-negative CM case on the milk yield loss for a second gram-negative CM case. During the last few weeks of lactation, CM cows regained their potential yield, actually surpassing the yield of non-CM cows.

The lactation curves for multipara with selected sequences of 3 cases of CM varied in shape (Figure 2C). All cases were assumed to occur during the median week of occurrence of CM case/type. Mastitic cows were higher producers before onset of CM, compared with nonmastitic cows. In particular, those whose first case was gram-negative produced approximately $2.5 \mathrm{~kg} / \mathrm{d}$ more milk before diagnosis compared with nonmastitic cows. Cows with a third gram-negative case returned 
Table 6. Milk yield loss $(\mathrm{kg} / \mathrm{d})$ estimates of mixed model of selected combinations of types of clinical mastitis $(\mathrm{CM})$

\begin{tabular}{|c|c|c|c|c|c|c|c|c|c|c|c|c|c|c|c|c|}
\hline \multirow[b]{3}{*}{ Time $^{2}$} & \multicolumn{4}{|c|}{ Gram-positive, gram-positive ${ }^{3}$} & \multicolumn{4}{|c|}{ Gram-positive, gram-negative $^{3}$} & \multicolumn{4}{|c|}{ Gram-negative, gram-positive ${ }^{3}$} & \multicolumn{4}{|c|}{ Gram-negative, gram-negative $^{3}$} \\
\hline & \multicolumn{2}{|c|}{ Gram-positive } & \multicolumn{2}{|c|}{ Gram-positive } & \multicolumn{2}{|c|}{ Gram-positive } & \multicolumn{2}{|c|}{ Gram-negative } & \multicolumn{2}{|c|}{ Gram-negative } & \multicolumn{2}{|c|}{ Gram-positive } & \multicolumn{2}{|c|}{ Gram-negative } & \multicolumn{2}{|c|}{ Gram-negative } \\
\hline & $\mathrm{Est}^{4}$ & $95 \% \mathrm{CI}^{5}$ & Est & $95 \%$ CI & Est & $95 \%$ CI & Est & $95 \%$ CI & Est & $95 \%$ CI & Est & $95 \%$ CI & Est & $95 \%$ CI & Est & $95 \% \mathrm{CI}$ \\
\hline Before CM & 0.3 & $\begin{array}{c}-0.1 \\
0.8\end{array}$ & - & - & 0.3 & $\begin{array}{c}-0.1 \\
0.7\end{array}$ & - & - & 1.0 & $\begin{array}{l}0.6, \\
1.4\end{array}$ & - & - & 1.0 & $\begin{array}{l}0.6, \\
1.4\end{array}$ & - & - \\
\hline Same week & -2.7 & $\begin{array}{l}-3.2 \\
-2.2\end{array}$ & -5.3 & $\begin{array}{l}-6.5 \\
-4.1\end{array}$ & -3.1 & $\begin{array}{l}-3.6 \\
-2.6\end{array}$ & -5.1 & $\begin{array}{l}-6.5 \\
-3.7\end{array}$ & -5.4 & $\begin{array}{l}-6.0 \\
-4.9\end{array}$ & -2.5 & $\begin{array}{l}-4.3 \\
-0.7\end{array}$ & -5.1 & $\begin{array}{l}-5.6 \\
-4.6\end{array}$ & -4.2 & $\begin{array}{l}-5.4 \\
-3.0\end{array}$ \\
\hline$+1 \mathrm{wk}$ & -2.5 & $\begin{array}{l}-3.1 \\
-1.9\end{array}$ & -4.2 & $\begin{array}{l}-5.7 \\
-2.6\end{array}$ & -2.8 & $\begin{array}{l}-3.3 \\
-2.2\end{array}$ & -5.5 & $\begin{array}{l}-7.4 \\
-3.7\end{array}$ & -5.5 & $\begin{array}{l}-6.1 \\
-4.9\end{array}$ & -4.6 & $\begin{array}{l}-7.3 \\
-1.9\end{array}$ & -5.7 & $\begin{array}{l}-6.4 \\
-5.1\end{array}$ & -4.1 & $\begin{array}{l}-5.6 \\
-2.6\end{array}$ \\
\hline$+2 \mathrm{wk}$ & -1.8 & $\begin{array}{l}-1.9 \\
-2.4 \\
-1.2\end{array}$ & -4.1 & $\begin{array}{l}-5.8 \\
-2.4\end{array}$ & -2.1 & $\begin{array}{l}-2.7 \\
-1.4\end{array}$ & -4.4 & $\begin{array}{l}-0.1 \\
-6.6, \\
-2.2\end{array}$ & -3.7 & $\begin{array}{l}-4.4 \\
-3.1\end{array}$ & -4.8 & $\begin{array}{l}-8.0 \\
-1.7\end{array}$ & -4.2 & $\begin{array}{l}-4.8 \\
-3.5\end{array}$ & -4.5 & $\begin{array}{l}-6.1 \\
-2.8\end{array}$ \\
\hline$+3 \mathrm{wk}$ & -1.6 & $\begin{array}{l}-2.2 \\
-0.9\end{array}$ & -4.7 & $\begin{array}{l}-6.4 \\
-2.9\end{array}$ & -1.6 & $\begin{array}{l}-2.3 \\
-1.0\end{array}$ & -4.4 & $\begin{array}{l}-6.8 \\
-2.0\end{array}$ & -2.1 & $\begin{array}{l}-2.8 \\
-1.5\end{array}$ & -2.1 & $\begin{array}{r}-5.5 \\
1.3\end{array}$ & -2.6 & $\begin{array}{l}-3.3 \\
-1.9\end{array}$ & -3.4 & $\begin{array}{l}-5.2 \\
-1.7\end{array}$ \\
\hline$+4 \mathrm{wk}$ & -1.1 & $\begin{array}{l}-1.8 \\
-0.5\end{array}$ & -4.9 & $\begin{array}{l}-6.9 \\
-2.9\end{array}$ & -1.3 & $\begin{array}{l}-1.9 \\
-0.6\end{array}$ & -4.4 & $\begin{array}{l}-6.8 \\
-1.9\end{array}$ & -1.6 & $\begin{array}{l}-2.3 \\
-0.9\end{array}$ & -1.4 & $\begin{array}{c}-5.0 \\
2.2\end{array}$ & -2.0 & $\begin{array}{l}-2.7 \\
-1.3\end{array}$ & -3.3 & $\begin{array}{l}-5.2 \\
-1.5\end{array}$ \\
\hline$+5 \mathrm{wk}$ & -1.1 & $\begin{array}{l}-1.7 \\
-0.4\end{array}$ & -4.5 & $\begin{array}{l}-6.7 \\
-2.3\end{array}$ & -1.2 & $\begin{array}{l}-1.8 \\
-0.5\end{array}$ & -2.2 & $\begin{array}{c}-4.7 \\
0.3\end{array}$ & -1.3 & $\begin{array}{l}-2.0 \\
-0.6\end{array}$ & -2.3 & $\begin{array}{c}-6.0 \\
1.5\end{array}$ & -1.7 & $\begin{array}{l}-2.3 \\
-1.0\end{array}$ & -3.6 & $\begin{array}{l}-5.5 \\
-1.6\end{array}$ \\
\hline$+6 \mathrm{wk}$ & -0.9 & $\begin{array}{l}-1.6 \\
-0.3\end{array}$ & -4.2 & $\begin{array}{l}-6.5 \\
-1.9\end{array}$ & -1.0 & $\begin{array}{l}-1.6 \\
-0.4\end{array}$ & -1.3 & $\begin{array}{c}-3.7 \\
1.0\end{array}$ & -1.0 & $\begin{array}{l}-1.7 \\
-0.3\end{array}$ & -4.3 & $\begin{array}{l}-8.1 \\
-0.5\end{array}$ & -1.3 & $\begin{array}{l}-2.0 \\
-0.6\end{array}$ & -2.9 & $\begin{array}{l}-4.8 \\
-0.9\end{array}$ \\
\hline$+7 \mathrm{wk}$ & -1.0 & $\begin{array}{l}-1.6 \\
-0.4\end{array}$ & -1.6 & $\begin{array}{c}-3.7 \\
0.6\end{array}$ & -0.9 & $\begin{array}{l}-1.5 \\
-0.3\end{array}$ & -1.3 & $\begin{array}{c}-3.6 \\
0.9\end{array}$ & -0.6 & $\begin{array}{r}-1.2 \\
0.1\end{array}$ & -2.0 & $\begin{array}{r}-5.6, \\
1.7\end{array}$ & -0.7 & $\begin{array}{l}-1.4 \\
-0.1\end{array}$ & -4.0 & $\begin{array}{l}-5.7 \\
-2.2\end{array}$ \\
\hline $\begin{array}{l}+8 \text { wk } \\
\text { and after }\end{array}$ & -1.0 & $\begin{array}{l}-1.4 \\
-0.5\end{array}$ & -1.9 & $\begin{array}{r}-3.7 \\
0.0\end{array}$ & -1.1 & $\begin{array}{l}-1.6 \\
-0.6\end{array}$ & 0.5 & $\begin{array}{c}-1.4 \\
2.5\end{array}$ & -0.2 & $\begin{array}{c}-0.7 \\
0.3\end{array}$ & -1.1 & $\begin{array}{c}-4.4 \\
2.1\end{array}$ & -0.3 & $\begin{array}{c}-0.8 \\
0.2\end{array}$ & -2.8 & $\begin{array}{l}-4.3 \\
-1.3\end{array}$ \\
\hline
\end{tabular}

${ }^{1}$ Combinations: 1) first case is oram-positive, second case is gram-positive; 2) first case is gram-positive, second case is gram-negative; 3 ) first case is gram-negative, second case is gram-positive; 4) first case is gram-negative, second case is gram-negative. Data are from 7,721 parity 1 cows on 7 New York State dairy farms.

${ }^{2}$ Time of milk measurement in relation to disease occurrence.

${ }^{3}$ Separate data sets; that is, "gram-positive, gram-positive" includes cows that had zero CM cases, and, if they had 2 or more CM cases, the first was gram-positive and the second was gram-positive. Estimates were obtained from a mixed model with an autoregressive covariance structure and random herd effect.

${ }^{4}$ Est $=$ estimate.

${ }^{5} \mathrm{CI}=$ confidence interval 

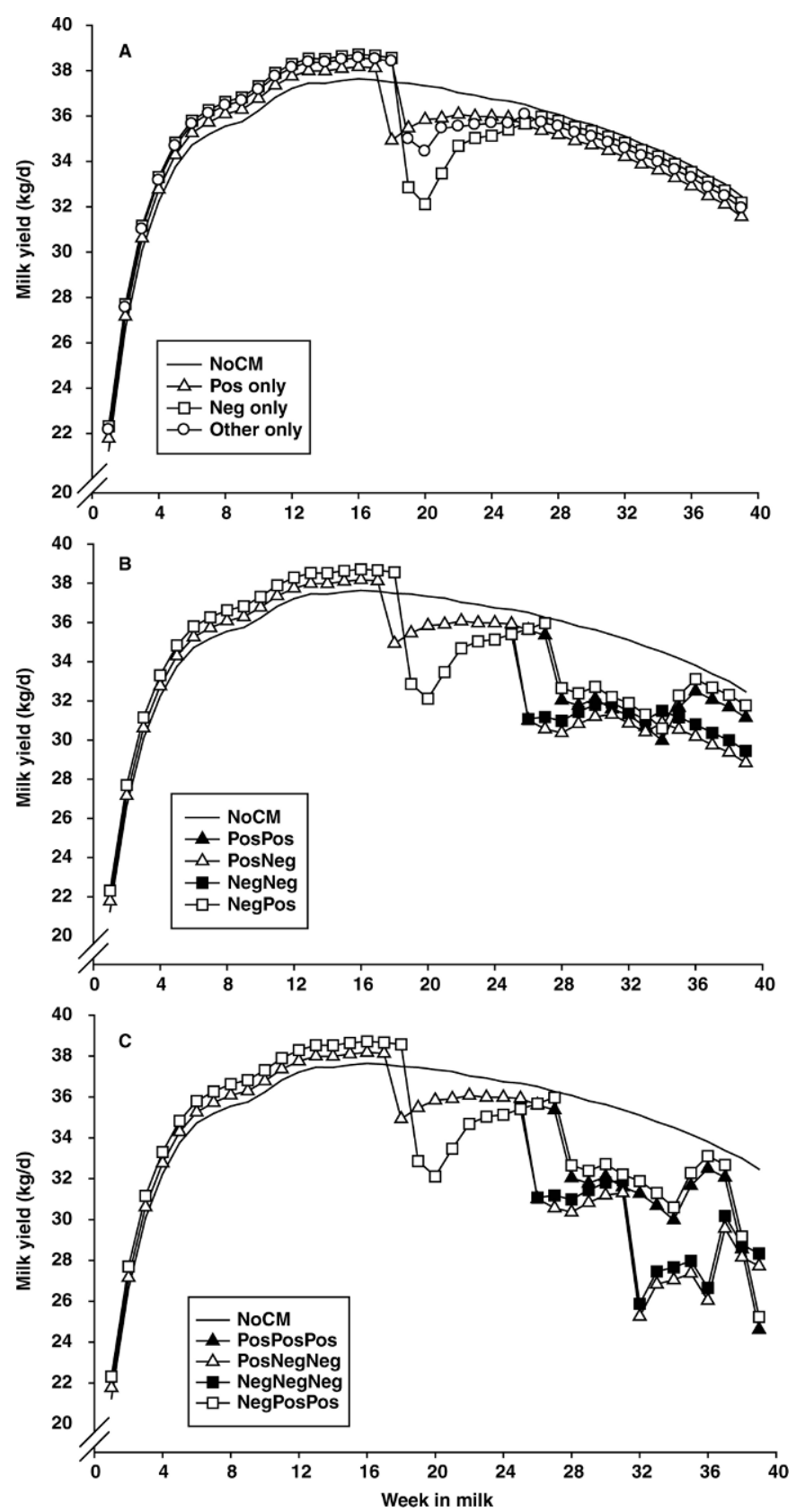

Figure 1. Lactation curves for A) primipara with no clinical mastitis $(\mathrm{CM} ;-)$, or only one case of 1 of 3 types of CM: gram-positive (Pos, $\Delta)$, gram-negative $(\mathrm{Neg}, \square)$, or other $(\bigcirc)$; cases are assumed to occur during the median week of occurrence for each type; B) primipara with no $\mathrm{CM}(-)$, or selected combinations of 2 cases of $\mathrm{CM}$ sequentially: PosPos $(\boldsymbol{\Lambda})$, PosNeg $(\Delta)$, NegPos $(\square)$, or NegNeg (ם); and $\mathrm{C}$ ) primipara with no $\mathrm{CM}(-)$, or selected combinations of 3 cases of CM sequentially: NegPosPos $(\square)$, PosNegNeg $(\Delta)$, PosPosPos $(\boldsymbol{\Lambda})$, or NegNegNeg (ם).

to near normal production by approximately 32 WIM as their third case occurred at approximately 24 WIM. Cows whose third case was gram-positive did return to near-normal production until approximately 35 WIM as their last case occurred at approximately 28 WIM.
In Figure 2C there was also no evidence of any protective effect of previous gram-negative $\mathrm{CM}$ cases on the milk loss in second or third gram-negative CM cases (compare NegNegNeg with PosNegNeg in Figure 2C).

\section{DISCUSSION}

Our results indicate that milk production losses were different, irrespective of the count of $\mathrm{CM}$, depending on the causal organism. The most severe milk loss was observed in the case of gram-negative mastitis, followed by gram-positive and "other" causes. Surprisingly, the severity of subsequent cases of CM as measured by milk production loss, both in kilograms of milk and percentage milk loss, remained approximately equal with increasing $\mathrm{CM}$ case number, and no evidence of reduced impact of a second or third mastitis case was present in our data. We also observed that a previous case of gram-negative or gram-positive mastitis did not protect against a subsequent case of $\mathrm{CM}$ with the same Gram-stain classification. For both gram-negative and gram-positive $\mathrm{CM}$, the incidence approximately doubled when a previous case had been experienced. Therefore, these data would indicate that there is no evidence for a protective immunological memory due to a previous exposure to an organism in the same generic class. Although this does not bode well for the potential efficacy of vaccines against either gram-positive or gram-negative CM, these observational data are clearly not as strong as those from randomized trials. In addition, cows with a second case of CM are likely the more susceptible animals in the population and possible not those in which vaccines employ their greatest efficacy. Finally, vaccination may use different routes of protection compared with natural cases. Vaccination is administered systemically, whereas a natural case occurs in the mammary gland, which might not result in a sufficient build-up of immunological memory.

When we focused on the severity (in terms of milk loss) of the second case of $\mathrm{CM}$ and evaluated whether a history of a similar or different type of CM (grampositive or gram-negative) was present in the first case, it became clear that the first case of CM had relatively little effect on the severity of subsequent cases (Tables 6 and 7). In both primipara and multipara (Table 6 and 7), having a first case of gram-positive mastitis was not protective for reduced severity in a second case of gram-positive mastitis. Similarly, a second case of gramnegative mastitis showed no protective effect when the first case was gram-negative compared with a first case of gram-positive CM. In all cases, a gram-negative CM case resulted in higher milk loss. For example, 7-wk milk loss due to a second case of gram-negative CM in multipara with a prior gram-positive case was 160 
Table 7. Milk yield loss $(\mathrm{kg} / \mathrm{d})$ estimates of mixed model of selected combinations of types of clinical mastitis $(\mathrm{CM})$

\begin{tabular}{|c|c|c|c|c|c|c|c|c|c|c|c|c|c|c|c|c|}
\hline \multirow[b]{3}{*}{ Time $^{2}$} & \multicolumn{4}{|c|}{ Gram-positive, gram-positive ${ }^{3}$} & \multicolumn{4}{|c|}{ Gram-positive, gram-negative $^{3}$} & \multicolumn{4}{|c|}{ Gram-negative, gram-positive ${ }^{3}$} & \multicolumn{4}{|c|}{ Gram-negative, gram-negative ${ }^{3}$} \\
\hline & \multicolumn{2}{|c|}{ Gram-positive } & \multicolumn{2}{|c|}{ Gram-positive } & \multicolumn{2}{|c|}{ Gram-positive } & \multicolumn{2}{|c|}{ Gram-negative } & \multicolumn{2}{|c|}{ Gram-negative } & \multicolumn{2}{|c|}{ Gram-positive } & \multicolumn{2}{|c|}{ Gram-negative } & \multicolumn{2}{|c|}{ Gram-negative } \\
\hline & $\mathrm{Est}^{4}$ & $95 \% \mathrm{CI}^{5}$ & Est & $95 \% \mathrm{CI}$ & Est & $95 \% \mathrm{CI}$ & Est & $95 \% \mathrm{CI}$ & Est & $95 \% \mathrm{CI}$ & Est & $95 \% \mathrm{CI}$ & Est & $95 \% \mathrm{CI}$ & Est & $95 \% \mathrm{CI}$ \\
\hline Before CM & 0.1 & $\begin{array}{r}-0.3 \\
0.5\end{array}$ & - & - & 0.6 & $\begin{array}{l}0.2, \\
1.0\end{array}$ & - & - & 1.9 & $\begin{array}{l}1.6, \\
2.3\end{array}$ & - & - & 1.8 & $\begin{array}{l}1.5 \\
2.2\end{array}$ & - & - \\
\hline Same week & -4.2 & $\begin{array}{l}-4.7 \\
-3.7\end{array}$ & -3.3 & $\begin{array}{l}-4.1 \\
-2.5\end{array}$ & -3.9 & $\begin{array}{l}-4.3 \\
-3.4\end{array}$ & -7.3 & $\begin{array}{l}-8.4 \\
-6.3\end{array}$ & -7.4 & $\begin{array}{l}-7.8 \\
-6.9\end{array}$ & -4.7 & $\begin{array}{l}-5.7 \\
-3.7\end{array}$ & -6.8 & $\begin{array}{l}-7.2 \\
-6.4\end{array}$ & -8.1 & $\begin{array}{l}-8.8 \\
-7.4\end{array}$ \\
\hline$+1 \mathrm{wk}$ & -3.7 & $\begin{array}{l}-4.2 \\
-3.2\end{array}$ & -3.8 & $\begin{array}{l}-4.7 \\
-2.8\end{array}$ & -3.7 & $\begin{array}{l}-4.2 \\
-3.2\end{array}$ & -5.6 & $\begin{array}{l}-6.9 \\
-4.3\end{array}$ & -10.4 & $\begin{array}{l}-10.9 \\
-10.0\end{array}$ & -4.4 & $\begin{array}{l}-5.6 \\
-3.2\end{array}$ & -9.7 & $\begin{array}{c}-10.2 \\
-9.3\end{array}$ & -7.9 & $\begin{array}{l}-8.8 \\
-7.1\end{array}$ \\
\hline$+2 \mathrm{wk}$ & -2.6 & $\begin{array}{l}-3.2 \\
-2.1\end{array}$ & -2.0 & $\begin{array}{l}-3.1 \\
-1.0\end{array}$ & -2.9 & $\begin{array}{l}-3.4 \\
-2.3\end{array}$ & -2.7 & $\begin{array}{l}-4.2 \\
-1.2\end{array}$ & -7.1 & $\begin{array}{l}-7.6 \\
-6.6\end{array}$ & -3.6 & $\begin{array}{l}-5.0 \\
-2.2\end{array}$ & -6.3 & $\begin{array}{l}-6.8 \\
-5.8\end{array}$ & -5.2 & $\begin{array}{l}-6.2 \\
-4.3\end{array}$ \\
\hline$+3 \mathrm{wk}$ & -2.1 & $\begin{array}{l}-2.7 \\
-1.5\end{array}$ & -1.4 & $\begin{array}{l}-2.5 \\
-0.2\end{array}$ & -2.3 & $\begin{array}{l}-3.0 \\
-1.7\end{array}$ & -1.5 & $\begin{array}{c}-3.2 \\
0.2\end{array}$ & -5.1 & $\begin{array}{l}-5.7 \\
-4.6\end{array}$ & -2.7 & $\begin{array}{l}-4.2, \\
-1.2\end{array}$ & -4.5 & $\begin{array}{l}-5.0 \\
-4.0\end{array}$ & -3.5 & $\begin{array}{l}-4.5 \\
-2.4\end{array}$ \\
\hline$+4 \mathrm{wk}$ & -1.8 & $\begin{array}{l}-2.4 \\
-1.2\end{array}$ & -1.0 & $\begin{array}{c}-2.3 \\
0.2\end{array}$ & -2.0 & $\begin{array}{l}-2.6 \\
-1.4\end{array}$ & -1.1 & $\begin{array}{r}-2.9 \\
0.7\end{array}$ & -3.9 & $\begin{array}{l}-4.4 \\
-3.3\end{array}$ & -2.3 & $\begin{array}{l}-3.9, \\
-0.6\end{array}$ & -3.5 & $\begin{array}{l}-4.0 \\
-2.9\end{array}$ & -2.4 & $\begin{array}{l}-3.5 \\
-1.3\end{array}$ \\
\hline$+5 \mathrm{wk}$ & -1.7 & $\begin{array}{l}-2.3 \\
-1.1\end{array}$ & 0.1 & $\begin{array}{r}-1.2 \\
1.4\end{array}$ & -1.7 & $\begin{array}{l}-2.3 \\
-1.1\end{array}$ & -0.1 & $\begin{array}{r}-2.0 \\
1.9\end{array}$ & -2.9 & $\begin{array}{l}-3.5 \\
-2.3\end{array}$ & -1.2 & $\begin{array}{r}-3.0 \\
0.5\end{array}$ & -2.4 & $\begin{array}{l}-2.9 \\
-1.9\end{array}$ & -1.5 & $\begin{array}{l}-2.7 \\
-0.4\end{array}$ \\
\hline$+6 \mathrm{wk}$ & -1.3 & $\begin{array}{l}-1.9 \\
-0.7\end{array}$ & 1.0 & $\begin{array}{l}-0.2 \\
2.3\end{array}$ & -1.1 & $\begin{array}{l}-1.7 \\
-0.4\end{array}$ & -0.2 & $\begin{array}{l}-2.1 \\
1.8\end{array}$ & -2.2 & $\begin{array}{l}-2.7 \\
-1.6\end{array}$ & -1.7 & $\begin{array}{c}-3.4 \\
0.1\end{array}$ & -1.9 & $\begin{array}{l}-2.4 \\
-1.3\end{array}$ & -1.2 & $\begin{array}{l}-2.4 \\
-0.0\end{array}$ \\
\hline$+7 \mathrm{wk}$ & -1.1 & $\begin{array}{l}-1.7 \\
-0.6\end{array}$ & -0.0 & $\begin{array}{c}-1.3 \\
1.2\end{array}$ & -0.8 & $\begin{array}{l}-1.3 \\
-0.2\end{array}$ & 0.7 & $\begin{array}{c}-1.1 \\
2.5\end{array}$ & -1.6 & $\begin{array}{l}-2.2 \\
-1.1\end{array}$ & -1.9 & $\begin{array}{l}-3.6 \\
-0.1\end{array}$ & -1.3 & $\begin{array}{l}-1.8 \\
-0.8\end{array}$ & 0.2 & $\begin{array}{c}-0.9 \\
1.4\end{array}$ \\
\hline $\begin{array}{l}+8 \text { wk } \\
\text { and after }\end{array}$ & -1.0 & $\begin{array}{l}-1.4 \\
-0.5\end{array}$ & 0.3 & $\begin{array}{c}-0.8 \\
1.4\end{array}$ & -0.5 & $\begin{array}{l}-1.0 \\
-0.0\end{array}$ & 1.6 & $\begin{array}{l}0.1 \\
3.2\end{array}$ & -1.3 & $\begin{array}{l}-1.7 \\
-0.8\end{array}$ & -1.3 & $\begin{array}{c}-2.9 \\
0.3\end{array}$ & -0.9 & $\begin{array}{l}-1.4 \\
-0.5\end{array}$ & 0.8 & $\begin{array}{c}-0.2 \\
1.8\end{array}$ \\
\hline
\end{tabular}

${ }^{1}$ Combinations: 1) first case is gram-positive, second case is gram-positive; 2) first case is gram-positive, second case is gram-negative; 3 ) first case is gram-negative, second case is gram-positive; 4) first case is gram-negative, second case is gram-negative. Data are from 13,566 parity $2+$ cows on 7 New York State dairy farms.

${ }^{2}$ Time of milk measurement in relation to disease occurrence.

${ }^{3}$ Separate data sets; that is, "gram-positive, gram-positive" includes cows that had zero CM cases, and, if they had 2 or more CM cases, the first was gram-positive and the second was gram-positive. Estimates were obtained from a mixed model with an autoregressive covariance structure and random herd effect.

${ }^{4}$ Est $=$ estimate.

${ }^{5} \mathrm{CI}=$ confidence interval 

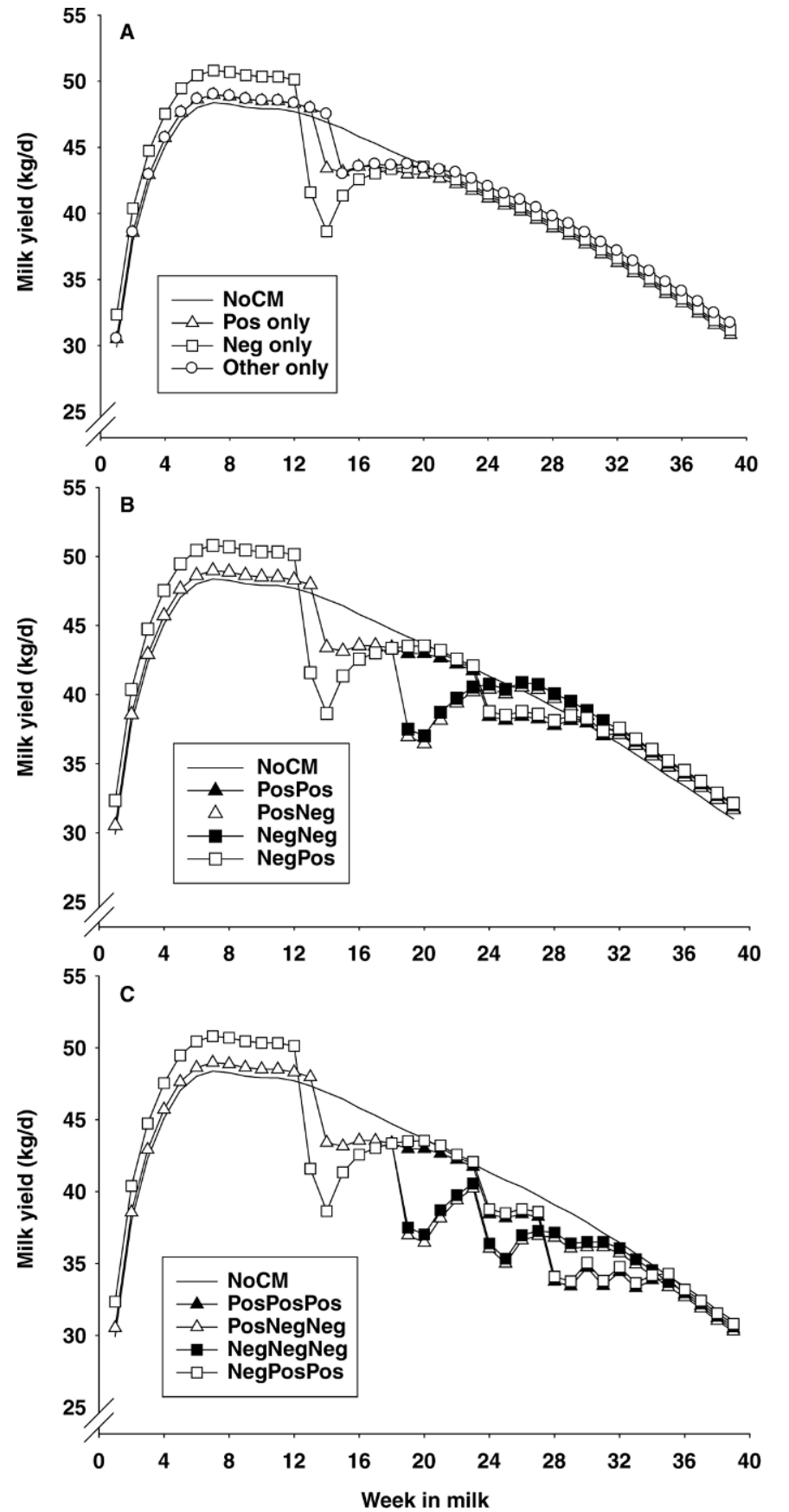

Figure 2. Lactation curves for A) multipara with no clinical mastitis $(\mathrm{CM} ;-)$, or one case of 1 of 3 types of CM: gram-positive (Pos, $\Delta)$, gram-negative $(\mathrm{Neg}, \square)$, or other $(\bigcirc)$; cases are assumed to occur during the median week of occurrence for each type; B) multipara with no CM (-), or selected combinations of 2 cases of CM sequentially: $\operatorname{PosPos}(\boldsymbol{\Lambda}), \operatorname{PosNeg}(\Delta), \operatorname{NegPos}(\square)$, or NegNeg (ם); and C) multipara with no CM $(-)$, or selected combinations of 3 cases of CM sequentially: NegPosPos $(\square)$, PosNegNeg $(\Delta)$, PosPosPos $(\boldsymbol{\Lambda})$, or NegNegNeg (ם). $\mathrm{kg}$, whereas 7 -wk milk loss was $308 \mathrm{~kg}$ when the first case was gram-negative. In multipara cows, milk losses were generally lower in second cases when the first case was gram-positive compared with gram-negative. These findings imply that when the first case in lactation is gram-negative, greater milk loss throughout lactation should be expected than when the first case is grampositive. Thus, multiparous cows with gram-negative CM may be good candidates for more aggressive treatment and follow-up, to minimize the effect of $\mathrm{CM}$ and enable their return to premastitic production levels sooner.

When comparing two subsequent experimental challenge infections with $E$. coli in the same cow after 14 d, Suojala et al. (2008) observed that after the second challenge local signs were significantly milder and disappeared faster. In that study, milk production returned to the prechallenge level significantly faster after the second challenge. However, in previous studies by the same research team (Rantala et al., 2002), again using an experimentally induced $E$. coli mastitis model and a 3 -wk challenge interval, the disease was slightly milder after the second challenge, but the differences were not statistically significant. In our data, the median interval between 2 gram-negative cases was approximately $9 \mathrm{wk}(63 \mathrm{~d})$ in both primipara and multipara. This would suggest that the 63-d interval would have resulted in the loss of any potential protection due to a previous gram-negative IMI. A similar finding, where vaccine efficacy of a core $\mathrm{J} 5$ antigen vaccine waned in approximately $13 \mathrm{wk}$, was recently reported by Wilson et al. (2008).

In a UK study, Milne et al. (2003) found that greater milk loss was a more likely consequence of a gramnegative IMI than a gram-positive IMI. This finding is in support of the observations in our study. It has been reported that although coliform mastitis reduced milk production for an extended time normal production resumed in the following lactation, implying that coliforms cause relatively little permanent damage to the udder (Zhao and Lacasse, 2008). Endotoxin LPS is considered a key factor for the pathogenicity of gramnegative bacteria. Accordingly, intramammary infusion of $E$. coli LPS is often used to study events occurring during gram-negative mastitis, as it mimics the symptoms of naturally occurring mastitis. When LPS was used to induce an inflammatory response in the mammary gland, it was observed that LPS does not cause tissue damage in vivo or in vitro in explants of lactating bovine mammary tissue (Zhao and Lacasse, 2008). In our observational data, we only observed repeated cases in the same lactation and we did observe that a first case of gram-negative CM was associated with more and longer term milk loss relative to gram-positive mas- 
titis. Hence, gram-negative infections appeared to have additional pathogenic components beyond the impact of LPS. This is in agreement with recent experimental studies in mice showing that a live bacteriological challenge in the mammary gland causes disease even when LPS receptors on cells of the immune system were not expressed (Gonen et al., 2007).

Morin et al. (1998) compared clinical parameters and milk production between cows with gram-positive CM and cows with gram-negative CM. No clinical parameters, except for rumen contraction rate [lower $(P=$ 0.0045) in gram-negative CM cows], differed between the 2 groups. Milk protein percentage was higher $(P=$ 0.004 ) before $\mathrm{CM}$ occurred in gram-negative $\mathrm{CM}$ cows than in gram-positive CM cows; milk fat percentage and milk production overall did not differ. All cows in the Morin et al. (1998) study had been vaccinated with the J5 E. coli bacterin. A possible reason for the lack of differences between cows affected with gram-positive and gram-negative $\mathrm{CM}$ is that, when $\mathrm{CM}$ does occur, the $\mathrm{J} 5$ vaccine by its nature results in less severe cases of gram-negative CM. It therefore can eliminate the distinction between effects of gram-positive and gramnegative CM.

Clinical mastitis cases were mostly detected by milkers on the dairy farm. In some cases however, milk conductivity was used to identify clinical mastitis. Because less severe cases may have a lower likelihood of detection by changes in milk conductivity, this may have resulted in a slight predominance of more severe cases in our data. However, this distribution of cases reflected what was truly observed and recorded on each of the dairies and hence reflects what dairy producers experience on their dairies.

This study was an extension of previous work done by our group (Bar et al., 2007) for recurrent cases of generic CM. At that time, we did not have sufficient case numbers to study the effects of specific pathogens or groups of pathogens. The data in the current study were, however, sufficient to divide the $\mathrm{CM}$ cases into 3 groups (gram-positive, gram-negative, and other). Such a grouping is logical and of practical use, because treatment protocols for gram-positive and gram-negative CM vary (Yazdankhah et al., 2001). In future research, with increasing case numbers, we plan to study the effects of individual pathogens (e.g., E. coli, Staph. aureus) in repeated CM cases on milk yield. Such information will help dairy farmers to refine their options to optimize decisions concerning management of their CM cows.

\section{ACKNOWLEDGMENTS}

The USDA (CSREES) Award No. 2005-35204-15714 provided funding for this study. The authors thank owners and personnel from the 7 dairies and the personnel of the Ithaca, Canton, and Geneseo Regional Laboratories, Quality Milk Production Services, for their valuable cooperation.

\section{REFERENCES}

Bannerman, D. D. 2008. Pathogen-dependent induction of cytokines and other soluble inflammatory mediators during intramammary infection of dairy cows. J. Anim. Sci. 87(Suppl. 1):10-25.

Bar, D., Y. T. Gröhn, R. N. González, J. A. Hertl, H. F. Schulte, G. J. Bennett, L. Tauer, and Y. H. Schukken. 2007. Effect of repeated episodes of generic clinical mastitis on milk yield in dairy cows. J. Dairy Sci. 90:4643-4653.

Barkema, H. W., Y. H. Schukken, T. J. Lam, M. L. Beiboer, H. Wilmink, G. Benedictus, and A. Brand. 1998. Incidence of clinical mastitis in dairy herds grouped in three categories by bulk milk somatic cell counts. J. Dairy Sci. 81:411-419.

Bartlett, P. C., J. van Wijk, D. J. Wilson, C. D. Green, G. Y. Miller, G. A. Majewski, and L. E. Heider. 1991. Temporal patterns of lost milk production following clinical mastitis in a large Michigan Holstein herd. J. Dairy Sci. 74:1561-1572.

Burton, J. L., and R. J. Erskine. 2003. Immunity and mastitis. Some new ideas for an old disease. Vet. Clin. North Am. Food Anim. Pract. 19:1-45.

Erskine, R. J., S. Wagner, and F. J. DeGraves. 2003. Mastitis therapy and pharmacology. Vet. Clin. North Am. Food Anim. Pract. 19:109-138.

Gonen, E., A. Vallon-Eberhard, S. Elazar, A. Harmelin, O. Brenner, I. Rosenshine, S. Jung, and N. Y. Shpigel. 2007. Toll-like receptor 4 is needed to restrict the invasion of Escherichia coli P4 into mammary gland epithelial cells in a murine model of acute mastitis. Cell. Microbiol. 9:2826-2838.

Gröhn, Y. T., R. N. González, D. J. Wilson, J. A. Hertl, G. J. Bennett, H. F. Schulte, and Y. H. Schukken. 2005. Effect of pathogenspecific clinical mastitis on herd life in two New York State dairy farms. Prev. Vet. Med. 71:105-125.

Gröhn, Y. T., D. J. Wilson, R. N. González, J. A. Hertl, H. Schulte, G. Bennett, and Y. H. Schukken. 2004. Effect of pathogenspecific clinical mastitis on milk yield in dairy cows. J. Dairy Sci. 87:3358-3374.

Houben, E. H. P., A. A. Dijkhuizen, J. A. M. van Arendonk, and R. Huirne. 1993. Short- and long-term production losses and repeatability of clinical mastitis in dairy cattle. J. Dairy Sci. $76: 2561-2578$.

Milne, M. H., A. M. Biggs, J. L. Fitzpatrick, G. T. Innocent, and D. C. Barrett. 2003. Use of clinical information to predict the characteristics of bacteria isolated from clinical cases of bovine mastitis. Vet. Rec. 152:615-617.

Morin, D. E., P. D. Constable, and G. C. McCoy. 1998. Use of clinical parameters for differentiation of gram-positive and gram-negative mastitis in dairy cows vaccinated against lipopolysaccharide core antigens. J. Am. Vet. Med. Assoc. 212:1423-1431.

Rantala, M., L. Kaartinen, E. Välimäki, M. Styrman, M. Hiekkaranta, A. Niemi, L. Saari, and S. Pyörälä. 2002. Efficacy and pharmacokinetics of enrofloxacin and flunixine meglumine for treatment of cows with experimentally induced Escherichia coli mastitis. J. Vet. Pharmacol. Ther. 25:251-258.

SAS Institute. 2006. SAS Online Doc 9.1.3. SAS Institute Inc., Cary, $\mathrm{NC}$.

Seegers, H., C. Fourichon, and F. Beaudeau. 2003. Production effects related to mastitis and mastitis economics in dairy cattle herds. Vet. Res. 34:475-491.

Silva, B. O., D. Z. Caraviello, A. C. Rodrigues, and P. L. Ruegg. 2005. Evaluation of Petrifilm for the isolation of Staphylococcus aureus from milk samples. J. Dairy Sci. 88:3000-3008.

Suojala, L., T. Orro, H. Järvinen, J. Saatsi, and S. Pyörälä. 2008. Acute phase response in two consecutive experimentally induced E. coli intramammary infections in dairy cows. Acta Vet. Scand. 50:18-24. 
Vasconcelos, J., A. Martins, M. F. Petim-Batista, J. Colaço, R. W. Blake, and J. Carvalheira. 2004. Prediction of daily and lactation yields of milk, fat, and protein using an autoregressive repeatability test day model. J. Dairy Sci. 87:2591-2598.

Wilson, D. J., and R. N. González. 2003. Vaccination strategies for reducing clinical severity of coliform mastitis. Vet. Clin. North Am. Food Anim. Pract. 19:187-197.

Wilson, D. J., R. N. González, J. Hertl, H. F. Schulte, G. J. Bennett, Y. H. Schukken, and Y. T. Gröhn. 2004. Effect of clinical mastitis on the lactation curve: a mixed model estimation using daily milk weights. J. Dairy Sci. 87:2073-2084.

Wilson, D. J., Y. T. Grohn, G. J. Bennett, R. N. González, Y. H. Schukken, and J. Spatz. 2008. Milk production change following clinical mastitis and reproductive performance compared among J5 vaccinated and control dairy cattle. J. Dairy Sci. 91:3869-3879.

Wilson, D. J., B. A. Mallard, J. L. Burton, Y. H. Schukken, and Y. T. Gröhn. 2007. Milk and serum J5-specific antibody responses, milk production change, and clinical effects following intramammary
Escherichia coli challenge for J5 vaccinate and control cows. Clin. Vaccine Immunol. 14:693-699.

Yancey, R. J. 1999. Vaccines and diagnostic methods for bovine mastitis: Fact and fiction. Adv. Vet. Med. 41:257-273.

Yazdankhah, S. P., S. Henning, H. J. S. Larsen, and G. Gogstad. 2001. Rapid method for detection of gram-positive and -negative bacteria in milk from cows with moderate or severe clinical mastitis. J. Clin. Microbiol. 39:3228-3233.

Zadoks, R. N., H. G. Allore, H. W. Barkema, O. C. Sampimon, G. J. Wellenberg, Y. T. Gröhn, and Y. H. Schukken. 2001. Cow and quarter-level risk factors for Streptococcus uberis and Staphylococcus aureus mastitis. J. Dairy Sci. 84:2649-2663.

Zhao, X., and P. Lacasse. 2008. Mammary tissue damage during bovine mastitis: Causes and control. J. Anim. Sci. 86:57-65. 